\title{
AN ANALYSIS OF THEME AND RHEME USED IN THE FIVE-STAR HOTELS' WEB SITES IN SURABAYA
}

\author{
Gabriel Stella ${ }^{1}$, Samuel Gunawan ${ }^{2}$ \\ 1,2 English Department, Faculty of Letters, Petra Christian University \\ Surabaya, East Java, Indonesia \\ E-mail: gabrielstella.widjaja@gmail.com¹; samgun@petra.ac.id ${ }^{2}$
}

\begin{abstract}
The study done by the writer observes the themes and rhemes used in the five-star hotels' web sites in Surabaya. It includes the types of themes and the notions of subject which are under the Systemic Functional Grammar (SFG) proposed by Halliday and Matthiessen (2004). In addition, the data of the study are in the form of text and taken from seven Surabaya five-star hotels' web sites. The writer also used a descriptive qualitative approach in analyzing the 155 data. From the analysis, it is found the two kinds of structure of theme and rheme used by the hotels in their web sites. The hotels also used three types of theme which are simple theme, clause as a theme, and thematic equative. In terms of the subjects (psychological subject, grammatical subject, and logical subject), the hotels are able to fulfill either one, two, or three notions of subject.
\end{abstract}

Key words: Theme and rheme, notions of subject, systemic functional grammar, hospitality web sites

\section{INTRODUCTION}

Nowadays, communication has become an essential thing as people live in a globalization era (Yuliana \& Rini, 2002). Through the languages, they can communicate many things with others. Generally, there are many ways to communicate; and one of them is through advertising. People must be familiar with what is called an advertising. Advertising is actually a process in which meaning or information is exchanged between individuals using some system of symbols, signs, or behavior (Arens, Weigold, and Arens, 2013, p.12). In the process of reaching the society, advertising cannot be accepted directly by people. It needs a channel of communication called a medium (Arens, Weigold, and Arens, 2013, p.12). As a medium, a web site is categorized as the type of internet advertising. It is closely related to where people can get knowledge and where information is stored. Hence, many businesses now are motivated to make use of the internet and the web site to promote the products or services.

Web sites deal a lot with appearance and content. Both the appearance and the content must do work to attract people (Cox \& Koelzer, 2004, p. 58). Besides, web sites should also be able to communicate well what the messages are. In this study, the writer sees that the structure of language used in web sites, especially in hospitality web sites, is not that simple as some people may not find it easier to understand the intended messages of the web sites. She also sees the practical application of the theory of theme and rheme proposed by Halliday and Matthiessen (2004) may be used to help hotels deliver their actual intention.

In addition, it is a fact that the web sites were used widely nowadays. Therefore, the writer becomes interested in studying further about it, especially the web sites used by hospitality businesses. She also has chosen seven web sites from seven five-star hotels in Surabaya to be analyzed. They are Bumi Surabaya City Resort, Ciputra World Hotel, Pullman Surabaya City Centre, Majapahit Hotel, Shangri-La Hotel, and Sheraton Hotel. Primarily, the writer attempts to analyze the themes and rhemes, including the types of theme and notions of subject used by those hotels in their web sites.

Thus, through this research, the writer intends to find out what kinds of structures of theme and rheme are used by those hotels in their web sites. Furthermore, she would like to find out how the themes organize the messages in the web sites of the hotels being investigated. Lastly, she also would like to find out how the subjects are used to organize the messages in the web sites of those hotels.

To provide answers to the research questions, the theory of theme and rheme including the types of theme and the notions of subject proposed by Halliday and Matthiessen (2004) was used in doing the analysis. Theme and rheme actually deals with a clause as a message. In English, as well 
as many other languages, there is a part in the clause that is assigned to have distinct status enunciated as the theme. Basically, the theme is the element serving as the departure point of the message and it locates and orients the clause within its context. Meanwhile, the rheme is the part where the theme is developed and it can also be called as the remainder of the message. When the theme is combined with the remainder, the rheme, it will constitute a message. Actually, the addresser can select the desired theme which results in the variation in what is chosen as the thematic element in the clause (Halliday \& Matthiessen, 2004, p.66). Moreover, sometimes the themes can also be declared explicitly by means of some expression to give the effect of focusing the theme such as as for..., with regard to..., about..., etc.

According to Halliday and Matthiessen (2004), there are mainly three types of theme which are simple theme, clause as a theme, and thematic equative. Simple theme consists of one, and only one, of the experiential elements (participant, circumstance, or process) (Halliday \& Matthiessen, 2004, p.79). Nominal groups, adverbial groups, prepositional phrases, and group or phrase complexes are still categorized as simple theme. Nominal group is the most common form of simple theme. Besides nominal group, the theme can be some other class of group or phrase (Halliday \& Matthiessen, 2004, p.66). Thus, sometimes the theme can also be adverbial groups and prepositional phrases. When the theme contain two or more groups or phrases (complex) forming a single structural element, it is called group or phrase complexes.

Besides simple theme, the theme can also be in the form of clauses. It happens because, in fact, in all major clause types, there is a thematic structure (Halliday \& Matthiessen, 2004, p.98). This kind of theme is categorized as dependent bound clauses either finite or non-finite. Another type of theme is thematic equatives. When the theme is a clause of a particular kind in which the theme and rheme structure are set up into a form of an equation (Theme=Rheme) is called thematic equative. There is also a relationship of identity or an equal sign expressed by the verb be to show that the theme is categorized as thematic equative.

Since the writer wants to find out how the subjects are used by the hotels, the theory of subject is also used. As an element in a clause, subject has three functions. However, there is no such element that embraces all the three functions. Therefore, the grammarians labeled three different kinds of subject which they believe that there is a general notion of subject covering all three (Halliday \& Matthiessen, 2004, p.56). They are psychological subject (the concern of the message), grammatical subject (that is being predicated), and logical subject (the doer of the action).

\section{METHODS}

The writer used a descriptive qualitative research approach in doing the analysis since she would deal more with texts instead of numbers. Furthermore, in this research, seven web sites of five-star hotels in Surabaya, owned by Bumi Surabaya City Resort, Ciputra World Hotel Surabaya, JW Marriot Hotel Surabaya, Majapahit Hotel Surabaya, Pullman Surabaya City Centre, Shangri-La Hotel Surabaya, and Sheraton Hotel Surabaya, became the source of the data. The reason why the writer chose five-star hotels was because five-star hotels gave more details and explanations in their web sites meaning there would be clauses and sentences that could be analyzed. Thus, the data would be in the form of texts which could be found in the two parts of the web sites which are 'about the hotel' and the descriptions of its rooms.

In collecting the data, the writer, firstly, surfed all the web sites of five-star hotels in Surabaya. Then, she explored and chose the parts of the web sites that could be analyzed. After that, she had to take the screenshots of the data to make them become valid as the hotel management might update the web site. This data were still raw data because the writer had not selected any data yet. Next, she grouped the data separately based on the hotels which were arranged alphabetically. Besides, she had to separate the data sentence by sentence or clause by clause. She also used a numbering system in which the data which had number 1 as the first digit belonged to Bumi Surabaya City Resort, number 2 as the first digit belonged to Ciputra World Hotel Surabaya, number 3 as the first digit belong to JW Marriot Hotel Surabaya, number 4 as the first digit belonged to Majapahit Hotel Surabaya, number 5 as the first digit belonged to Pullman Surabaya City Centre, number 6 as the first digit belonged to Shangri-La Hotel Surabaya, and number 7 as the first digit belonged to Sheraton Hotel Surabaya. Actually, the collected data were 198 in total, but only 155 data were able to show the structure of theme and rheme. It happened because some data were in the 
form of noun or incomplete sentence such as 'A feeling of home with every heartfelt gesture' found in Shangri-La Hotel Surabaya's web site and 'Indulge Your Psyche' found in Ciputra World Hotel Surabaya's web site. These kinds of data would be excluded by the writer. After those steps were done, she was ready to analyze the data.

She began to analyze the boundary between theme and rheme by using the theory proposed by Halliday and Matthiessen (2004). After that, the data were put into the table of theme and rheme so that the writer could do further analysis in the types of theme (simple theme, clause as a theme, and thematic equative) and the notions of subject (psychological subject, grammatical subject, and logical subject). After analyzing all the data, the writer would put the results as in the following table.

Table... Hotel...

Table 1. Data Analysis

\begin{tabular}{|l|l|l|l|l|l|l|l|l|l|}
\hline \multirow{2}{*}{ No. } & \multirow{2}{*}{ Theme } & \multirow{2}{*}{ Rheme } & \multicolumn{6}{|c|}{ Types of theme } & \multicolumn{3}{c|}{$\begin{array}{c}\text { Notions of subject } \\
\text { occupying the } \\
\text { theme }\end{array}$} & \multirow{2}{*}{ Notes } \\
\cline { 4 - 9 } & & & ST & CT & TE & PS & GS & LS & \\
\hline & & & & & & & & & \\
\hline & & & & & & & & & \\
\hline & & & & & & & & & \\
\hline & & & & & & & & & \\
\hline
\end{tabular}

ST: Simple theme

CT: Clause as a Theme

TE: Thematic Equative
PS: Psychological Subject

GS: Grammatical Subject

LS: Logical Subject

Then, she would be able to discuss how the types of theme and the notions of subject were used in organizing the messages.

\section{FINDINGS AND DISCUSSION}

There are two structures of theme and rheme used by the hotels in their web sites. The first one is the subject which is placed before the verb as the theme, and the rest is the rheme. The second one is the phrase or clause which is placed before a coma and in front of the subject as the theme, and the rest is the rheme. The first structure definitely can be found in all of those hotels' web sites and it is the basic structure proposed by Halliday and Matthiessen (2004). The following table shows a data that uses the first structure of theme and rheme.

Table 2. Structure 1 Used in the Hotels' Web Sites

\begin{tabular}{|c|c|c|}
\hline No. & \multicolumn{1}{|c|}{ Theme } & \multicolumn{1}{c|}{ Rheme } \\
\hline 1.6 & $\begin{array}{l}\text { Every room and suite at } \\
\text { Bumi Surabaya }\end{array}$ & $\begin{array}{l}\text { offers classic home comforts and panoramic views } \\
\text { over the surrounding city. }\end{array}$ \\
\hline
\end{tabular}

As in 1.6, Bumi Surabaya City Resort arranges 'Every room and suite at Bumi Surabaya' as the theme as it simply concerns about the rooms and the suites.

The second structure is used when the hotels need to give an effect of emphasizing or focusing on certain things, but the hotels decide which messages that need to use this structure. We can still find this structure is applied by several hotels. Only Pullman Surabaya City Centre does not use the second structure at all. The following table shows a data that uses the second structure of theme and rheme.

Table 3. Structure 2 Used in the Hotels' Web Sites

\begin{tabular}{|l|l|l|}
\hline No. & \multicolumn{1}{|c|}{ Theme } & \multicolumn{1}{c|}{ Rheme } \\
\hline 1.24 & $\begin{array}{l}\text { Characterized by a refined } \\
\text { sense of style, }\end{array}$ & $\begin{array}{l}\text { the Classic Executive Suite generously covers } \\
125 \text { square meters. }\end{array}$ \\
\hline
\end{tabular}

As in 1.24, owned by Bumi Surabaya City Resort, 'Characterized by a refined sense of style' is set as the theme to give focusing effect to 'the Classic Executive Suite'. 
The first and most common type of theme is simple theme. It is usually realized by a nominal group, adverbial group, prepositional phrase, group complex, or phrase complex. According to Halliday and Matthiessen (2004), as long as the theme constitutes a single element within the clause, it is still categorized as simple theme although the form can vary. The following table shows some data that are categorized as simple theme.

Table 4. Simple Themes Used in the Hotels' Web Sites

\begin{tabular}{|l|l|l|}
\hline No. & \multicolumn{1}{|c|}{ Theme } & \multicolumn{1}{c|}{ Rheme } \\
\hline 5.3 & $\begin{array}{l}\text { The breathtaking views of the } \\
\text { city skyline }\end{array}$ & will guarantee a truly memorable stay. \\
\hline 6.28 & At Shangri-La, & $\begin{array}{l}\text { we understand that true luxury means quality } \\
\text { time well spent. }\end{array}$ \\
\hline 1.1 & $\begin{array}{l}\text { An exquisite accommodation } \\
\text { for your business, leisure, and } \\
\text { authentic traditional dining } \\
\text { experiences }\end{array}$ & nestled in Surabaya downtown area. \\
\hline 2.6 & $\begin{array}{l}\text { From architectural taste and } \\
\text { function to every single } \\
\text { amenity, }\end{array}$ & $\begin{array}{l}\text { Ciputra World will spoil the customers from } \\
\text { the moment they arrive at the location. }\end{array}$ \\
\hline
\end{tabular}

In 5.3, the theme is also in the form of a nominal group. It is about the amazing views of the city skyline from Pullman Surabaya City Centre that will make a memorable stay for the customers. In 6.28 , the theme is in the form of a prepositional phrase, but it points out a place. It just simply states that only in Shangri-La, the true luxury means quality time well spent is understood well. In 1.1, the theme is in the form of a group complex in which it is about Bumi Surabaya City Resort that provides a very good accommodation for business and leisure, and also special dining experiences that are in the center of Surabaya. In 2.6, the theme is in the form of a prepositional complex. It is about Ciputra World Hotel's architecture and amenity which will make the customers amaze instantly when they arrive at the hotel. We can conclude that simple theme does have many variation in term of the form, but still the theme just want to deliver one point of the message.

Besides, the hotels sometimes set clauses as the theme, and it can be another alternative in organizing their messages. Clauses that are found in the hotels' web sites are mainly categorized as dependent bound clauses either finite or non-finite meaning they cannot stand alone and need another clause to constitute a complete idea. We may not be able to see the point of the message clearly when the theme is in the form of a dependent clause. Only Ciputra World Hotel, JW Marriot Hotel, Shangri-La Hotel, and Sheraton Hotel which have clauses as a theme. The following table shows a clause which is set as a theme.

Table 5. Clause as a Theme Used in the Hotels' Web Sites

\begin{tabular}{|l|l|l|}
\hline No. & \multicolumn{1}{|c|}{ Theme } & \multicolumn{1}{c|}{ Rheme } \\
\hline 2.9 & $\begin{array}{l}\text { Whether you choose a room } \\
\text { with a queen bed or twin bed, }\end{array}$ & $\begin{array}{l}\text { each room is completed with high quality } \\
\text { furnishings and artistic decor. }\end{array}$ \\
\hline
\end{tabular}

As in 2.9, the clause is categorized as a finite dependent bound clause. When the reader reads the theme, it will be perceived as a choice of room. Whereas, Ciputra World Hotel actually wants to inform that each room is completed with artistic decor no matter which room it is.

Lastly, we can also find another type of theme which is called thematic equative. The purpose of this type of theme is basically to clarify what has been the theme. In this type of theme, the rheme is actually the clarification of the theme and vice versa. This type of theme seems to be used by all the hotels. The following table shows a data that is categorized as thematic equative.

Table 6. Thematic Equative Used in the Hotels' Web Sites

\begin{tabular}{|l|c|l|}
\hline No. & \multicolumn{1}{|c|}{ Theme } & \multicolumn{1}{c|}{ Rheme } \\
\hline 1.2 & Bumi Surabaya City Resort & $\begin{array}{l}\text { is a classic city resort in the heart of the city or } \\
\text { just 40 minutes from the International Juanda } \\
\text { Airport. }\end{array}$ \\
\hline
\end{tabular}


As in 1.2, 'a classic city resort in the heart of the city or just 40 minutes from the International Juanda Airport Bumi Surabaya City Resort' is the nominalization. The hotel actually wants to clarify that Bumi Surabaya City Resort itself is the classic city resort in the heart of the city or just 40 minutes from the International Juanda Airport.

Besides the types of theme, the writer also analyze how the subjects are used by the hotels in their web sites. There are three notions of subject which are psychological subject, grammatical subject, and logical subject. These three notions occupy the theme and can be fulfilled at once or separately depending on the hotels in organizing the messages. The following table shows several data in which the themes fulfill either one notion of subject, two notions of subject, or three notions of subject.

Table 7. Notions of Subject Used in the Hotels' Web Sites

\begin{tabular}{|l|l|l|}
\hline No. & \multicolumn{1}{|c|}{ Theme } & \multicolumn{1}{c|}{ Rheme } \\
\hline 6.13 & $\begin{array}{l}\text { With seven restaurants and } \\
\text { bars, }\end{array}$ & The choices at your disposal pose a challenge \\
\hline 2.13 & 72 Grand Deluxe guestrooms & $\begin{array}{l}\text { are designed with warm and welcoming } \\
\text { interiors that await discerning travelers } \\
\text { whether they choose a room with king bed or } \\
\text { Hollywood twin beds. }\end{array}$ \\
\hline 1.21 & Each suite & $\begin{array}{l}\text { features a large walk-in closet, bathroom with } \\
\text { a separate standing shower and long bath } \\
\text { equipped with an exclusive bathroom set such } \\
\text { as bathtub tray, loofah, bathsalts, as well as } \\
\text { herbal amenities to pamper your bubble bath } \\
\text { time. }\end{array}$ \\
\hline
\end{tabular}

In 6.13, the theme fulfills only one notion of subject. 'With seven restaurants and bars,' is the only concern of the hotel. It means the hotel try to emphasize that those restaurants and bars will challenge your choice. In 2.13, the theme fulfills only two notions of subject. ' 72 Grand Deluxe guestrooms' is the concern of the message and put in front of a verb 'are designed' showing that it is being predicated. However, it is not the one who designs the room. The hotel want to emphasize that the rooms are designed with warm and welcoming interiors which await the customers. In 1.21, 'Each suite' fulfills the three notions of subject at once. The hotel sets 'Each suite' as the concern of the message. It also puts 'Each suite' in front of a verb 'feature' showing that it is being predicated, and 'Each suite' will be the one who will feature those complete room facilities.

From the findings, there are several things that we can pay attention to. Firstly, there are mainly two kinds of structure of theme and rheme used in those hotels' web sites. It is shown that the hotels still rely on the first structure or basic structure of theme and rheme in arranging the messages in the web sites instead of using the second structure which has been a variation.

Secondly, from the overall data in each hotel, we can conclude that in organizing the messages, the hotels mainly use three types of theme which are simple theme, clause as a theme, and thematic equative. By using simple theme, it means the hotels tend to use a group of words in organizing and delivering their messages since it contains the concern of the message and will be more easily understood. Moreover, we can also find themes which are in the form of clauses. As the reader may not be able to grab directly the idea of the message because of a dependent clause, the hotels try to avoid using clauses as a theme. Only Ciputra World Hotel Surabaya, JW Marriot Hotel Surabaya, Shangri-La Hotel Surabaya, and Sheraton Hotel Surabaya use some clauses as the theme. Besides simple theme and clause as a theme, thematic equative is also used in the hotels' web sites. Actually, the hotels use thematic equative only when they need to clarify something. If it is already clear or no need to be clarified, the hotels will use simple theme since it has more variation in term of the forms.

Furthermore, the writer also found that the themes used in those hotels are able to fulfill either one notion of subject, two notions of subject, or three notions of subject at once. When the hotels try to describe the features of the hotel or the room, the themes will fulfill the three notions of subject at once. She also found that the themes and rhemes which fulfill two notions of subject, Psychological Subject and Grammatical Subject, commonly are in the form of passive sentences. 
Basically, every hotel has a different way of organizing the messages. When only psychological subject is fulfilled, it means the hotels only want to emphasize the concern of the message. When psychological subject and grammatical subject are fulfilled, it means the hotels want to emphasize not only the concern of the message, but also the grammatical arrangement. Meanwhile, if the three notions of subject (psychological subject, grammatical subject, and logical subject) are fulfilled at once, it means the hotel pay attention very well to the concern of the message, the grammatical arrangement, and the doer of the action. By choosing and arranging those types of theme and notions of subject, the hotels primarily want to deliver clear and understandable messages to the readers.

\section{CONCLUSION AND SUGGESTIONS}

In this research, the writer observed the themes and rhemes used in five-star hotels' web sites in Surabaya. Basically, through the research, she wanted to know how the hotels organize their messages in their web sites so that it will be understandable to the readers. In doing the research, the writer used a descriptive qualitative approach. Moreover, she used the theory of theme and rheme (including types of theme and notions of subject) proposed by M.A.K. Halliday \& Christian M.I.M. Matthiessen (2004) as the theory. The data were taken from the web sites owned by Bumi Surabaya City Resort, Ciputra World Hotel Surabaya, JW Marriot Hotel Surabaya, Majapahit Hotel Surabaya, Pullman Surabaya City Centre, Shangri-La Hotel Surabaya, and Sheraton Hotel Surabaya. The data of this research were texts, and there were 155 data which were analyzed in this research.

After analyzing the data, the writer found that mainly there are two kinds of structure of theme and rheme used in the web sites. The first structure is the subject which is placed before the verb as the theme, and the rest is the rheme. The second structure is the phrase or clause which is placed before a coma and in front of the subject as the theme, and the rest is the rheme. In fact, the hotels still rely on the first structure or basic structure of theme and rheme.

There are mainly three types of theme which are simple theme, clause as a theme, and thematic equative used by the hotels in their web sites. Simple theme is usually in the form of a group of words and has many variation in term of the form. That is purposed to deliver clear and attractive messages to the readers. In addition, the writer found some clauses become the theme. From the data, it is seen that the hotels attempt to avoid to use clauses as a theme because the reader may not be able to grab directly the idea of the message. Besides simple theme and clause as a theme, the hotels sometimes also use thematic equative in the way they organize their messages. This type of theme is used for clarifying what the hotels need to clarify.

In terms of the use of notions of subject, each hotel basically has a different way of organizing the messages. The themes can fulfill either one notion of subject, two notions of subject, or three notions of subject. Some themes only emphasize the concern of the message (psychological subject). Some others emphasize not only the concern of the message (psychological subject), but also the grammatical arrangement (grammatical subject). Others emphasize the concern of the message (psychological subject), the grammatical arrangement (grammatical subject), and the doer of the action (logical subject). That depends which things that the hotels want to emphasize.

Through the findings and analysis, we can now see how the hotels organize their messages in their web sites. Lastly, the writer hopes many people will be attracted in doing further research in the themes and rhemes used in the hospitality web sites so that there will be improvements of the knowledge.

\section{REFERENCES}

Arens, W. F., Weigold, M. F., \& Arens, C. (2013). Contemporary advertising \& integrated marketing communication $\left(14^{\text {th }} \mathrm{ed}\right.$.). New York: McGraw Hill/Irwin.

Cox, B. and Koelzer, W. (2004). Internet marketing in hospitality. NJ: Prentice-Hall.

Halliday, M.A.K. \& Matthiessen, C. M.I.M. (2004). An introduction to functional Grammar (3 ${ }^{\text {rd }}$ ed.). London: Hodder Education.

Yuliana \& Rini, J. E. (2002). Introduction to communication. Jakarta: PT Grasindo. 